\title{
Preliminary Report on a Stratified Late Archaic-Woodland Era Rockshelter in Rogers County, Oklahoma
}

Robert W. Jobson Jr.

U.S. Army Corps of Engineers

Frank Winchell

A. E. Picarella

Kiven C. Hill

Follow this and additional works at: https://scholarworks.sfasu.edu/ita

Part of the American Material Culture Commons, Archaeological Anthropology Commons, Environmental Studies Commons, Other American Studies Commons, Other Arts and Humanities Commons, Other History of Art, Architecture, and Archaeology Commons, and the United States History Commons

Tell us how this article helped you.

This Article is brought to you for free and open access by the Center for Regional Heritage Research at SFA ScholarWorks. It has been accepted for inclusion in Index of Texas Archaeology: Open Access Gray Literature from the Lone Star State by an authorized editor of SFA ScholarWorks. For more information, please contact cdsscholarworks@sfasu.edu. 


\section{Preliminary Report on a Stratified Late Archaic-Woodland Era Rockshelter in Rogers County, Oklahoma}

\section{Creative Commons License}

\section{(c) (1) \&}

This work is licensed under a Creative Commons Attribution-NonCommercial 4.0 International License 


\title{
PRELIMINARY REPORT ON A STRATIFIED LATE ARCHAIC-WOODLAND ERA ROCKSHELTER IN ROGERS COUNTY, OKLAHOMA
}

\author{
Robert W. Jobson, Jr., Frank Winchell, A. E. Picarella, and Kevin C. Hill \\ U.S. Army Corps of Engineers, Tulsa District
}

\section{Introduction}

In northeastern Oklahoma, very little is known about the transition from the Late Archaic to the Woodland period (Wyckoff and Brooks, 1983: 55). To date, most of the archeological evidence documenting this time period has been derived from sites with mixed or otherwise uncertain components (Vehik 1984:178). In this report, we present a preliminary description of a small rockshelter, 34RO252, which has a Late Archaic deposit stratigraphically below a Woodland era cultural deposit. These two deposits are unmixed, discrete, and are physically separated by an apparently sterile clay soil horizon. It is anticipated that the stratified cultural deposits at this site will help characterize the transition from the Late Archaic to the Early Woodland period along the Verdigris River in northeast Oklahoma.

This site was first reported in April 1994 by two men who had discovered partially exposed human skeletal remains located in the rear remnant of a rockshelter at Oologah Lake in Rogers County, Oklahoma (Figure 1). The two men illegally excavated the remains and removed them from the site.' The rockshelter where the remains originated was subsequently examined by the authors and additional skeletal material was identified, in situ, in an exposed soil profile (Figure 2). A series of three radiocarbon assays, described below, placed the cultural deposit and the human remains within the Late ArchaicWoodland period (circa 780 B.C. to A.D. 900). ${ }^{2}$ This site is provisionally classified as corresponding to a cultural sequence that includes the old Grove C (Delaware A)/Woodland II (Cooper foci) described by Purrington (1971:11, 531ff) and Vehik (1984:178-179; 1994:239ff).

\section{Environmental Setting}

Site $34 \mathrm{RO} 252$ is located in the Claremore Cuesta Plains on the side of a fossiliferous limestone bluff which is on the west bank of and overlooks the old Verdigris River channel. The Verdigris River is currently under Oologah Lake. The base of the rockshelter stands at 680 feet National Geodetic Vertical Datum. Above the rockshelter, sediments overlying the limestone uplands consist of a silty clay loam of the Newtonia-Sogn-Summit association which had originally developed under a cover of tall prairie grasses (Polone 1966:2). Today, the uplands in this vicinity are predominantly forested with oak and hickory. On top of the bluff above the rockshelter there is a small stand of cedar trees. 


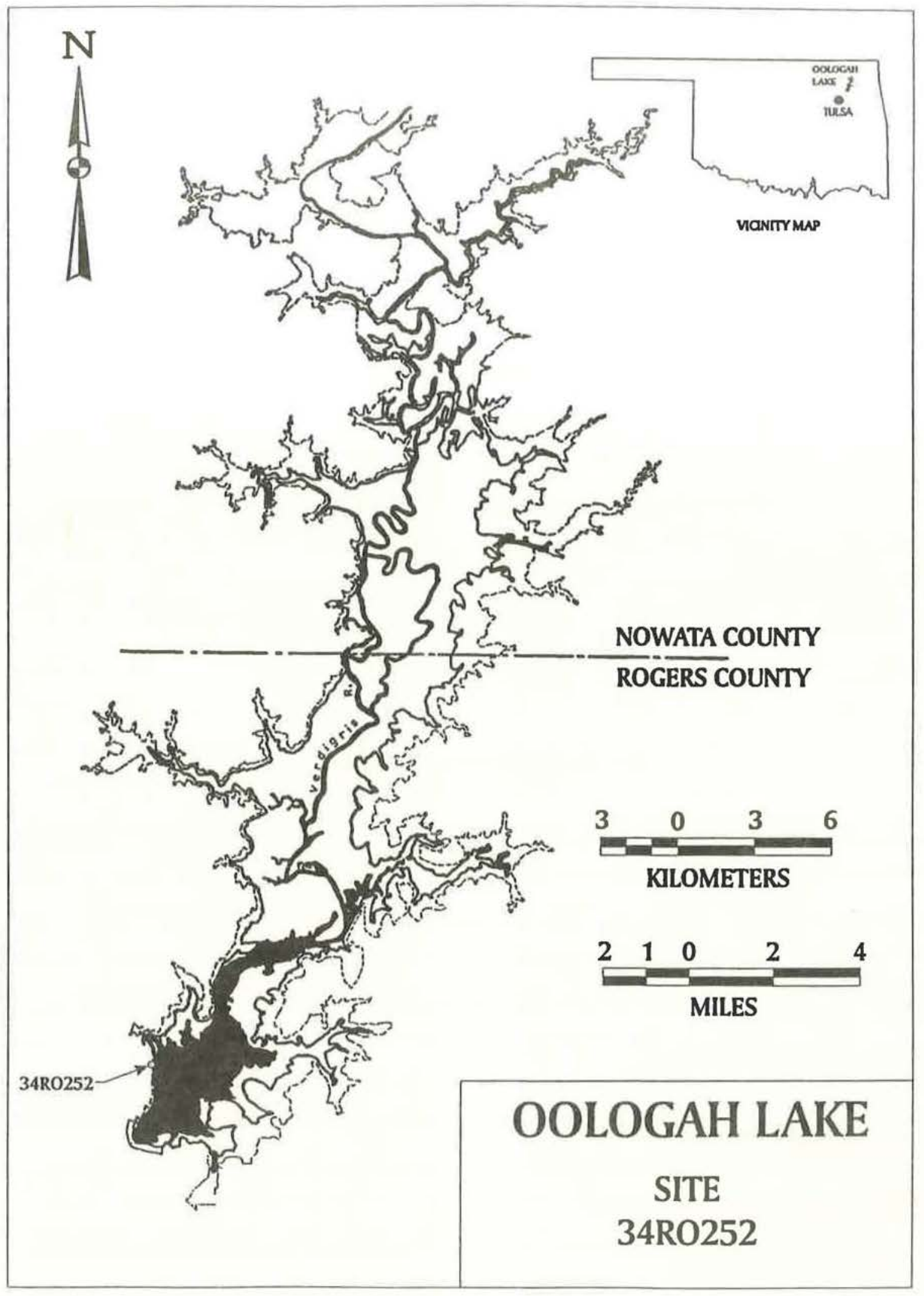

Figure 1. Location of Rockshelter Site (34RO252). 


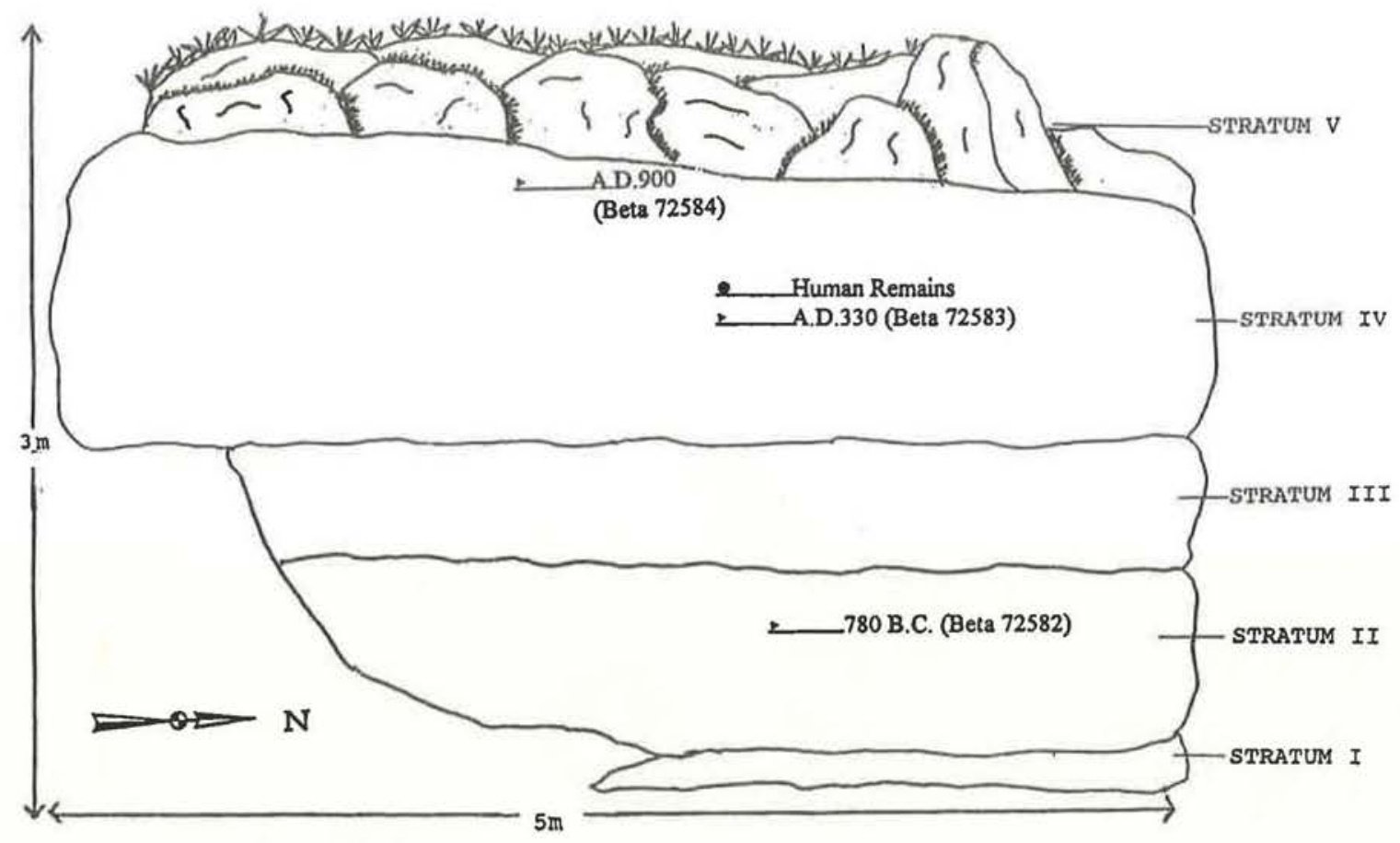

Figure 2. Soil Profile Schematic, 34RO252.

\section{Archeological Background}

Little is known about the time leading up to and during the Delaware A Focus in northeastern Oklahoma. Because of limited data and mixed or otherwise uncertain assignments distinguishing differences between the Late Archaic and the Early Woodland period in northeast Oklahoma has been difficult (Vehik 1984; Wyckoff and Brooks 1983:55). Purrington (1971) and Vehik (1984) suggest, however, that the Delaware A Focus emerged gradually from the Late Archaic Grove $\mathrm{C}$ Focus. The gradual transition out of the Late Archaic is marked by a shift in the frequency from barbed points to Late Contracting Stemmed points (Purrington 1971:535). Contracting stemmed points, such as Gary, Langtry, and Standlee predominate the chipped stone assemblage of the Delaware A Focus. These points are linked to the Late Archaic and post-Woodland occupations, however, and as a result, dating sites based on these artifacts is difficult. Grit ceramics consisting of bowl and jar forms with conoidal-flat disc bases are present in small amounts and resemble Woodward Plain ware forms of the later Neosho Focus. Nonceramic Delaware A deposits are not uncommon, however. While dating this transition has been extremely poor, Vehik (1984) proposes that the Delaware A Focus begins at about A.D. 1.

Delaware A deposits are found in both rockshelters and open air sites. Because there is a narrower range of artifacts found at rockshelters than at open air sites, it has been suggested that the rockshelters were used for specific functions like hunting. This observation might also account for the absence of ceramics in these deposits. At one Delaware A site, mussel shell makes up $80 \%$ of the faunal assemblage, suggesting a limited 
resource base (Vehik 1984). In some deposits, an increased frequency of milling equipment and tools associated with horticulture indicate a shift towards subsistence based on cultigens.

Most of the basic changes, or lack of changes as the case may be, in northeast Oklahoma does suggest however, that the early Woodland period and the later cultural sequences correspond to an in situ development rather than migration into the territory (Vehik 1994:156). Consistent with Vehik's thesis that the southern Plains CaddoanWichita tradition developed in place over a long period of time $(1992 ; 1993 ; 1994)$, we think that site $34 \mathrm{RO} 252$ is part of that in place development and that those cultures identified during the Woodland and post-Woodland era were established at a much earlier time.

\section{Site Description}

It is emphasized that this is a preliminary report on 34RO252. All descriptions here are based on what was observed on the surface of the site. Additional work at 34RO252 may, and probably will, change some of the description presented in this report.

Site 34RO252 consists of a small rockshelter just below the crest of an east-facing, precipitous bluff overlooking the submerged Verdigris River channel (Figure 1). At its closest point, it is estimated that $34 \mathrm{RO} 252$ is 100 meters west by southwest of and raises 35 meters above the Verdigris River. The rockshelter itself is no more than 20 meters long (north to south) and 5 meters wide (east to west). A large section of the roof of the shelter has collapsed and lays down slope just below the remaining intact cultural deposit. Most of the cultural deposit has slumped down slope.

The principal evidence of human activity at this site is the presence of human remains. The skeletal remains come from a single individual. Some of the skeletal remains were observed in situ in the exposed soil profile (Figure 2). Most of what remains at the site, however, consists of two small vertically stratified cultural deposits. These deposits have lenses of ash and flecks of charcoal. There is a great deal of mussel or clam shell embedded in the matrix of the cultural deposits at this site. Small fragments of turtle carapace are also present. Chert flakes are present in low density. To date, no ceramics or formal stone tools have been identified at this site.

There are two apparently intact and unmixed cultural strata sandwiched in between three apparently sterile soil horizons present at the site. Figure 2 illustrates the strata described here. Stratum I is approximately $5 \mathrm{~cm}$ thick and consists of a red clay non-cultural horizon that forms the basement of this stratigraphic sequence. Stratum II rests immediately on Stratum I. Stratum II is a discrete cultural deposit approximately $70 \mathrm{~cm}$ thick. It consists of a dark brown to black clayey loam. There are flecks of charcoal in this deposit. Freshwater mussels or clam shells appear to be embedded in Stratum II. The upper third of Stratum II was dated to circa 780 B.C. Stratum III rests immediately on Stratum II. Stratum III is approximately $15 \mathrm{~cm}$ thick and consists of a noncultural brownish red clay horizon. Stratum IV rests immediately on Stratum III. Stratum IV looks very much like Stratum II. It consists of a carbon rich, dark brown to black clayey loam. The human remains originate in Stratum IV. Stratum IV has a great deal of mussel or clam shell embedded in its matrix. One small piece of turtle carapace came from Stratum IV. A radiocarbon sample taken from soil tangent to the in situ skeletal remains yielded a date of circa A.D. 330. A radiocarbon sample taken from the top of Stratum IV yielded a date of circa A.D. 900. Stratum V is a non-cultural horizon of roof fall/detritus that caps the entire deposit. 
The structure and age of this site suggests that there are two discrete cultural components present at this site. They are physically separated by a well defined non-cultural soil horizon (Stratum
III in Figure 2). The lower component dates to the Late Archaic. The upper component spans the Woodland period.

\section{Radiocarbon Dates and Chronological Placement}

Based on a series of three radiocarbon assays the occupation of the rockshelter dates between 810 B.C. and A.D. 1010 (Table 1). These assays are within two standard deviations $(2 \sigma)$ with a $95 \%$ probability that the site dates to this range. The radiocarbon dates were derived from carbonrich sediments within Stratum II and Stratum IV. The earliest date (Beta-72582) was recovered from Stratum II and has a $2 \sigma$ range from 810 B.C. to 420 B.C., with a mean date of 780 B.C. The remaining dates were taken from Stratum IV. Beta 72583 was recovered immediately below and tangent to the in situ human remains exposed in the soil profile. This sample has a range, within $2 \sigma$, between A.D. 210 and A.D. 420 , with a mean date of A.D. 330 . The youngest date, (Beta 72584) was recovered from the top of Stratum IV and ranges, within $2 \sigma$, be- tween A.D. 780 and A.D. 1010, with a mean date of A.D. 900.

Among the three radiocarbon dates there is no overlap, even within a range of $2 \sigma$. It appears that Stratum II is, at the very least, 600 years earlier than Stratum IV. In Stratum IV, the two assays are separated by at least 350 years.

Chronologically, the occupation of Stratum II dates to the late Archaic, while Stratum IV fall predominately within the Woodland period. Along this portion of the Verdigris River the cultural chronology is vague. However, based on the dates and geographic placement of the site, 34RO252 appears to have been occupied during the old Grove C (Delaware A)/Woodland II (Cooper foci) described by Vehik (1984:178ff).

Table 1. Radiocarbon Assays From Samples Recovered at 34RO252.

\begin{tabular}{ccc}
\hline \hline Sample & $\begin{array}{c}\text { Conventional Radiocarbon } \\
\text { Age BP }(1 \sigma)\end{array}$ & $\begin{array}{c}\text { Calibrated Age } \\
(1 \sigma)\end{array}$ \\
\hline Strat. II (Beta 72582) & $2540 \pm 60$ & \\
Strat. IV (Beta 72583) & $1740 \pm 50$ & $\begin{array}{c}810-420 \mathrm{BC} \\
(x=780 \mathrm{BC})\end{array}$ \\
Strat. IV (Beta 72584) & $1140 \pm 50$ & $\begin{array}{c}\text { AD 210 }-420 \\
(x=\text { AD 330) }\end{array}$ \\
& & $\begin{array}{l}\text { AD 780 - 1010 } \\
(x=\text { AD 900) }\end{array}$ \\
\hline \hline
\end{tabular}




\section{Summary and Conclusions}

To conclude, $34 \mathrm{RO} 252$ is a stratified rockshelter that has two discrete unmixed components that were deposited during the Late Archaic and the Woodland periods. In contrast, most of the sites that date to this transitional period have had mixed deposits or doubtful assignments (Vehik 1984). Thus far, observations of $34 \mathrm{RO} 252$ seems consistent with Vehik's (1984) characterization of a hard to see and difficult to define Delaware A Focus described for the Neosho River drainage just to the east. The site chronologically spans the Early and later Woodland period but, thus far, no ceramics have been identified at the site. Like other rockshelters that date to the Delaware A Focus, there is a great deal of mussel or clam shell present at 34RO252. Thus far, the burial present at this site does not have observable grave furniture, ${ }^{3}$ a characteristic of the Delaware A Focus noted by Vehik (1984).

One of two outcomes can be expected from further examination of $34 \mathrm{RO} 252$. If there is no difference between the earlier and later deposits, this would appear to support the proposition that there was very little change or that the change was very gradual between the Late Archaic and Woodland periods for this part of Oklahoma. A gradual change may argue for a conservative in situ cultural transition. If the two deposits are measurably different from one another, for example, in terms of ceramics, cultigens, and faunal remains, inter alia, these differences may help illustrate the nature of the transition from the Late Archaic to the Woodland period for this part of Oklahoma. A pronounced or punctuated change might argue for immigration or invasion.

As it stand now, site $34 \mathrm{RO} 252$ is consistent with other Delaware A/Woodland II era sites and appears to reflect a gradual, conservative in place transition from the Late Archaic to the Woodland era. If that is the case, then an argument could reasonably be made that the cultural affiliation of this site is ancestral to the late prehistoric and early historic era Wichita-speakers that occupied this territory. This is an idea consistent with Vehik's argument for an in situ development of the pan-Caddo/Wichita-speaking people in the central and southern Plains.

Salvage excavation of this site is underway and a more detailed picture of the material present will be forthcoming.

\section{ENDNOTES}

1. The two men subsequently turned the remains over to law enforcement officials, who turned the remains over to the Medical Examiner's Office, Tulsa, Oklahoma.

2. The Medical Examiner's Office would not release the remains to Tulsa District unless there was evidence that the remains were not the result of recent wrong doing. After one of us (Jobson) examined the remains at the Medical Examiner's Office, it was concluded that it was extremely probably that the remains were Native American and ancient. The three radiocarbon dates were taken to convince the Medical Examiner's Office that the remains were in fact ancient and Native American. Based on these dates, the remains were released to Tulsa District.

3. The two men who excavated and removed the remains did not report finding any grave furniture. 


\section{REFERENCES}

Polone, Dock J.

1966 Soil Survey of Rogers County. United States Government Printing Office, Washington, D.C.

\section{Purrington, $\mathrm{B}$.}

1971 The Prehistory of Delaware County, Oklahoma: Cultural Continuity and Change on the Western Ozark Periphery. Ph.D. dissertation, University of Wisconsin, Madison. University Microfilms International, Ann Arbor.

Vehik, S.C.

1984 The Woodland Occupations. Prehistory of Oklahoma, edited by R.E. Bell, pp. 175-197. Academic Press, Orlando.
1992 Wichita Culture History. Plains Anthropologist 37(141):311-332.

1993 Dhegiha Origins and Plains Archaeology. Plains Anthropologist 38(146):231-252.

1994 Cultural Continuity and Discontinuity in the Southern Prairies and Cross Timbers. In Plains Indians, A.D. 500-1500: Archaeological Past of Historic Groups, edited by Karl H. Schlesier, pp. 239-263. University of Oklahoma Press, Norman.

Wyckoff, Don G., and Robert L. Brooks 1983 Oklahoma Archeology: A 1981 Perspective. Oklahoma Archeological Survey, Archeological Resource Survey Report 16. Norman. 